Harvard Kennedy School Misinformation Review ${ }^{1}$

May 2020, Volume 1, Special Issue on COVID-19 and Misinformation

Creative Commons Attribution 4.0 International ( $\underline{\mathrm{CC} \mathrm{BY} \mathrm{4.0}}$ )

Reprints and permissions: misinforeview@hks.harvard.edu

DOI: https://doi.org/10.37016/mr-2020-022

Website: misinforeview.hks.harvard.edu

\title{
Blame is in the eye of the beholder: Beyond an ethics of hubris and shame in the time of COVID-19
}

As misinformation and disinformation spread more rapidly and widely than ever before, individuals have been encouraged to be critical consumers of all received information. At the heart of this point of contention is the question of where responsibility and fault should lie. This framing and dynamic have taken a new form during the COVID-19 pandemic: a risk that the narrative of victim-blaming may overcome narratives of care and responsibility, at all levels and across national contexts. This begs the question of which ethical assumptions individuals and institutions will build upon in navigating the crisis and developing policies and best practices for everyday life, as well as for what will come next?

Author: Annalisa Pelizza

Affiliation: Department of Philosophy and Communication Studies, University of Bologna, Italy

How to cite: Pelizza, A. (2020). Blame is in the eye of the beholder: Beyond an ethics of hubris and shame in the time of

COVID-19. Harvard Kennedy School (HKS) Misinformation Review, I(3).

Received: March 31 ${ }^{\text {st }}, 2020$. Published: May 27 $7^{\text {th }}, 2020$.

\section{Hubristic reactions to the COVID-19 pandemic}

Invoking nature's wrath is an old trope, going back to ancient Greek myths and moral texts where hubris referred to transgressions of the boundaries between gods and humans. The myths of Icarus, Cassiopeia, Tantalus, and Arachne are just a few examples of humans who challenged the gods, pushed their own natural limits, and were punished for their arrogance. It is this meaning of hubris that was inherited by modernity through myths like Faust.

But in ancient Greece, there was a second meaning of hubris developed in civil speeches and tractates, something along the lines of what we today might call "victim shaming." In Against Midias, Demosthenes (384-322/1939) uses the term hubris to indicate both verbal and physical assault. In the Rhetoric, Aristotle refers to hubris as the practice of shaming the victim: "hubris consists in acts and words that cause shame to the victim, not in order to obtain advantage for oneself besides the act itself, but simply for the pleasure of it" (Rhetoric 1378b, Author's translation) (Aristotle, 385-322/1926). As in ancient moral systems, shame is a form of public dishonor, hubris entails the relationship of public devaluation so that the counterpart can claim their status or be raised higher in comparison.

Rather than transcendental arrogance against the gods, it is this earthly form of hubris, shaming the victim, that characterizes many reactions to the COVID-19 pandemic, even in significantly

\footnotetext{
${ }^{1}$ A publication of the Shorenstein Center for Media, Politics and Public Policy, at Harvard University, John F. Kennedy School of Government.
} 
distinctnational and trans-national contexts. And it is with this understanding that I will analyze and contextualize the COVID-19 pandemic.

\section{The politics of shaming the victim}

Under the strict lockdown orders of Italy, individuals walking or jogging alone in deserted areas are regularly shamed as Manzonian infectors (Manzoni, 1827/2011). Videos of Italian mayors condemning citizens who have ventured out of their homes, even when respecting physical distancing guidelines, have gone viral and been featured on broadcasts all around the world with little public consideration for whether such stigmatization or enforcement is proportionate or effective (Jackson \& Cavendish de Moura, 2020). In similar cases, a hubris mechanism is in place: the victim - the locked-in citizen - is to be shamed.

In the Netherlands, the politics of shaming the victim takes subtler but no less insidious forms, where individuals less likely to survive the contagion are encouraged to be role models for the rest of the population and give up their place in intensive care units to those with higher odds of surviving COVID-19 (Weeda, 2020). In such framings, the weight of important public policy decisions and strategies of how best to manage the pandemic are shifted on to the individual, absolving those in power and the institutions they lead.

Such a rhetorical tactic requires unpacking and some contextualization. The objective problem many countries are now facing is the insufficient ratio of ventilators to the number of individuals infected and in need of ventilation (ventilators/patients $<1$ ). As in algebraic division, the problem can be described as having too low a dividend (i.e., too few ventilators) or too high a divisor (i.e., too many patients in need of ventilators). Choosing to allocate the cause of the problem either to the dividend or to the divisor is not a neutral choice, it is a political framing with ethical implications.

Indeed, framing the insufficient ratio as a problem of too few ventilators puts responsibility on healthcare policymakers and suggests a concrete policy measure: greater investment in acquiring more machines and improving the healthcare system. On the other hand, framing the insufficient ratio as a problem of too many patients shifts responsibility on to individual citizens and suggests individual solutions; as in the case described earlier from the Netherlands, older and immune-compromised patients should give up ventilators to younger, "healthier" patients-shaming those who refuse to conform to this standard.

\section{Hubris in COVID-19-informed international relations}

This kind of hubris is not limited to national governments and its citizenry but is extended to international relations, as well. On March 25, former president of the European Central Bank Mario Draghi (2020) specified that "the loss of income is not the fault of any of those who suffer from it" (para. 14). A claim that certainly needed to be restated, particularly with respect to negotiations taking place between members of the European Council (EU-Staaten wollen neues Modell für gemeinsamen Rettungsschirm ausarbeiten, 2020; Malingre, 2020; Cillis, 2020; De Miguel, 2020). On the one hand, nine European countries severely affected by the virus had asked for immediate shared financial tools, backed by European institutions, to mitigate COVID-19 disruptions, even recognizing how such tools might further bind together these states and potentially relinquish some of their financial sovereignty (Governo italiano presidenza del consiglio dei ministri, 2020). On the other hand, some ministers of finance had called for an investigation into past fiscal management of the countries seeking support from the European Union and refused the criteria for loans to be relaxed (Peeperkorn, 2020). Financially conservative countries indeed argue that the current inability to cope with the pandemic is a consequence of past financial dysfunctions. 
Whatever the outcome of the debate for the future of Europe, it is evident that it revolves around the hubristic behavior that pushes the victim to face not only the violence of the pandemic, but also the violence of shame.

Against currently resurgent feelings of nationalism, these examples show that hubris is not a national trait, but an attitude in the face of disasters. Confronting such catastrophe, a hubristic response can see humans either invoke gods' wrath or identify the root cause in other humans (i.e., the plague is a god's response to human arrogance vs. the resulting hardship of a plague is based on specific individual failures). This latter form of hubris is an attitude of the powerful for power's sake. And, where the former understanding of hubris does not leave much room to maneuver, as it is rooted in supernatural deeds beyond human control, more possibilities of action can be devised within this latter form of hubris. This shame indeed requires two things: a distinction between "Us" and "Them" as well as framing the situation as a zero-sum game.

\section{Two recommendations for scholars, policymakers, and journalists}

Regarding the distinction, we might want to ask how "them" became "Them" and "us" became "Us," that is, which criteria are mobilized to create and reproduce these distinctions. How are well-worn narratives of the unruly citizen and other bigoted stereotypes resurrected to find fault and validate austerity and other such grave decisions? What are the alternative narratives that might instead lead to policies of care and mutual aid?

As for the zero-sum game, it corresponds to Aristotle's definition of hubris as a relationship in which a rise in status for the perpetrator is only obtained by publicly shaming the victim. By shaming Italian runners, the credibility of those mayors is strengthened. By shaming the elderly, the efficiency of the Dutch healthcare system is reaffirmed. By shaming China or Spain, the superiority of the United States and Northern Europe is proven. Or, at least, so some believe. We should instead question this zero-sum game on which hubris and its ethics of shame are based.

As scholars, policymakers, and journalists, in these gloomy days we need an ethics beyond shame, an ethics that is able a) to account for how old tropes are resurrected and utilized to push for current goals, and make those tropes known to the public; b) to avoid building policies on assumptions of zero-sum games. Such an ethics is urgent and necessary to rebut the re-emerging narratives around biological and financial infectors. A better future cannot be built on the ruins of a social fabric where officers despise their citizens and the young sacrifice the elderly.

\section{Bibliography}

Aristotle. (1926). Aristotle in 23 volumes (Vol. 22). (J. H. Freese, Trans.). Harvard University Press; William Heinemann. (Original work published ca. 385-322 B.C.)

Cillis, L. (2020, March 26). Coronavirus, consiglio europeo: Raggiunto un accord dopo l'attacco di conte. La Repubblica. https://www.repubblica.it/economia/2020/03/26/news/conte alla ue se aiuti gli saranno co me in passato facciamo da soli -252410637/

De Miguel, B. (2020, March 27). El plan de choque europeo encalla por la resistencia de Alemania y Holanda. El País. https://elpais.com/economia/2020-03-26/el-plan-de-reactivacion-enfrenta-ala-ue-en-su-mayor-crisis-sanitaria.html

Demosthenes. (1939). Demosthenes with an English translation. (A. T. Murray, Trans.). Harvard University Press; William Heinemann. (Original work published ca. 384-322 B.C.) 
Draghi, M. (2020, March 25). Draghi: We face a war against coronavirus and must mobilise accordingly. Financial Times. https://www.ft.com/content/c6d2de3a-6ec5-11ea-89df-41bea055720b

EU-Staaten wollen neues Modell für gemeinsamen Rettungsschirm ausarbeiten. (2020, March 26). Frankfurter Allgemeine Zeitung. https://www.faz.net/aktuell/politik/inland/oekonomischepandemie-folgen-eu-einigt-sich-auf-weiteres-vorgehen-in-corona-krise-16698750.html

Governo italiano presidenza del consiglio dei ministri. (2020, March 25). Coronavirus, la lettera al presidente del consiglio europeo Charles Michel. http://www.governo.it/it/articolo/coronavirusla-lettera-al-presidente-del-consiglio-europeo-charles-michel/14378

Jackson, A., \& Cavendish de Moura, H. (2020, March 24). Italian mayors are scolding residents for disobeying lockdown orders. CNN. https://edition.cnn.com/2020/03/23/world/italian-mayorsscolding-residents-coronavirus-lockdown-trnd/index.html

Malingre, V. (2020, March 27). Coronavirus: Au conseil européen, les vingt-sept ébauchent la suite. La Monde. https://www.lemonde.fr/economie/article/2020/03/27/coronavirus-au-conseileuropeen-les-vingt-sept-ebauchent-la-suite $6034628 \quad 3234 . \mathrm{html}$

Manzoni, A. (2011). The betrothed: From the Italian of Alessandro Manzoni. Project Gutenberg. (Original work published 1827).

Peeperkorn, M. (2020, March 24). Hoekstra stribbelt tegen bij steunpakket EU: 'Een Nederlandse middelvinger naar het zuiden'. Del Volkskrant. https://www.volkskrant.nl/nieuwsachtergrond/hoekstra-stribbelt-tegen-bij-steunpakket-eu-een-nederlandse-middelvinger-naarhet-zuiden b94cd15b/

Weeda, F. (2020, March 20). Als je overlevingskans klein is, beland je in Nederland niet op de intensive care. NRC Handelsblad. https://www.nrc.nl/nieuws/2020/03/20/als-je-overlevingskans-klein-isbeland-je-in-nederland-niet-op-de-intensive-care-a3994450 


\section{Copyright}

This is an open access article distributed under the terms of the Creative Commons Attribution License, which permits unrestricted use, distribution, and reproduction in any medium, provided that the original author and source are properly credited. 